\title{
University mathematics students' study habits and use of learning materials
}

\author{
Timo Tossavainen ${ }^{1}$, Janne Gröhn², Lasse Heikkinen³, Anna Kaasinen ${ }^{3}$ \\ and Antti Viholainen ${ }^{2}$ \\ ${ }^{1}$ Department of Arts, Communication and Education, Lulea University of Technology, Sweden \\ 2 Department of Physics and Mathematics, University of Eastern Finland \\ ${ }^{3}$ Department of Applied Physics, University of Eastern Finland
}

In this article, we report from a group $(N=98)$ of students from two campuses of one Finnish university, on their study habits, and to what extent they use different kinds of learning materials in university mathematics courses. Our results show that the older students are more communicative with their teachers, whereas the younger students ask for help more often from fellow students. The sociomathematical norms that constitute the local study culture have a significant impact on the study habits and on the use of learning materials. For example, the use of videos and studying lecture materials before the lectures were clearly more usual at one campus than at the other. We also found some significant differences between the groups that are based on the study programmes. The students of mathematics without an intention to become a teacher were most traditional in their study habits, whereas the students of applied physics were most active to participate in teaching. The student teachers most often lie in the middle in the issues where the other groups differ from one another. Quite unexpectedly, students' previous performance in upper secondary school does not explain the differences in the study habits in the university.
Article Details

LUMAT General Issue Vol 8 No 1 (2020), 252-270

Received 27 March 2020 Accepted 30 September 2020 Published 5 October 2020

Pages: 19

References: 26

Correspondence: timo.tossavainen@Itu.se

https://doi.org/10.31129/ LUMAT.8.1.1317

Keywords: learning material, mathematics, student, university

\section{Introduction}

The Finnish universities that offer courses and programmes in mathematics are facing a new kind of challenge in 2019-2020, as they for the first time meet a whole student generation that, in upper secondary school, has continuously studied mathematics in a digital learning environment and taken the national matriculation exam in such a milieu instead of using paper and pen. This raises the question: what kind of methods and media we should use for delivering mathematical knowledge to these students in university mathematics courses.

This article aims at providing some facts for this discussion by investigating mathematics students' study habits at one Finnish university and, especially, how actively students use various learning materials available to them. Further, we survey how variation in these issues relates to variation in the students' previous study 
performance. In Finland, the grades in the national matriculation exams are generally assumed to summarise the performance in upper secondary school well. Hence, they play a fundamental role in admission to university; a good overview of Finnish upper secondary education, the matriculation examination, and how they are related to admission to university is given by Kupiainen, Marjanen, and Hautamäki (2016). We also explore whether one can notice some differences in the study habits and use of learning materials between different student generations.

There are obviously many factors that influence students' study habits and use of learning materials. For example, self-efficacy in mathematics and views of the nature of mathematics is related to the general motivation and performance in mathematics (e.g., Stevens, Olivárez, Lan, \& Tallent-Runnels, 2004; Tossavainen, Rensaa, \& Johansson, 2019) which in turn affect how actively students participate in teaching and use learning materials. On the other hand, individuals' motivation and selfefficacy in mathematics vary quite a lot during the years (e.g., Tossavainen \& Juvonen, 2015). Yet there are longitudinal studies showing that students' performance at the end of upper secondary school can be quite well predicted from their achievement in the earlier years, cf. Metsämuuronen (2017). Moreover, parents' educational background also plays a significant role here and the effect is seen already in primary and lower secondary school (ibid.). In other words, there are also more permanent elements in a student's educational history that have a significant impact on his/her study habits and thereby on the achievement.

Sociomathematical norms (Yackel \& Cobb, 1996) have a dynamic impact on students' activities in the teaching and learning of mathematics. It has been reported that these norms and their effects may vary even between single courses at the same institution (e.g. Roy, Tobias, Safi, \& Dixon, 2014). One reason for that is that the norms in the classroom are formed and develop in interaction with a teacher and students, and teachers of a different kind steer this process in different directions.

Further, a student's personal properties such as sociality also play a significant role when it comes to study habits and, e.g., using social platforms for searching for mathematical knowledge.

The present study is a part of a larger investigation on the university mathematics students' study habits. In this article, we focus on the effects that are related to a student's educational background, study programme, and the differences between the sociomathematical norms on the involved campuses. Further, we divide the respondents into two groups (which we call the younger and older students) according 
to that whether they have taken the national matriculation exam in mathematics under the most recent national core curriculum or not. The new core curriculum was implemented in August 2016 and it necessitates the use of digital learning environments also in mathematics. Our specific research questions are as follows.

1. How do the national matriculation exam grades in mathematics and mother tongue explain the variation in the respondents' study habits and use of learning materials in university?

2. Do the older and younger university students differ from one another with respect to their study habits or use of learning materials?

3. How do the students of different programmes or campuses differ from one another as users of learning materials and in their study habits?

The first question may look somewhat strange at first sight as we do not try to explain students' performance with the aid of study habits or use of learning materials, but we do in the opposite way. A motivation for this is as follows. As we already mentioned, in Finland, the grades in the national matriculation exams in mathematics and mother tongue are used as central indicators of the expected success in academic studies at the admission to higher education (Kupiainen, Marjanen, \& Hautamäki, 2016; Kupiainen, 2017). Therefore, we want to survey to what extent these grades are really related to the variation in study habits in university. An implicit hypothesis here is that, for example, versatile use of learning materials and social study habits are beneficial and productive for studying mathematics in university, cf. Holzinger, Kickmeier-Rust, \& Albert (2008) and Blasco-Arcas, Buil, Hernández-Ortega, \& Sese (2013).

In order to answer the third question, we make a comparison of three groups: 1) the student teachers, 2) the students of pure or applied mathematics, and 3) the students of applied physics with mathematics as a minor subject. The first and second groups study at one campus, the third group at the other. For further information, see the method section.

The overview of students' study habits and use of learning materials will be contained in answer to the last question. 


\section{Theoretical framework}

In this study, we consider the participants' expressed study habits in the framework of sociomathematical norms. Yackel and Cobb (1996, p. 460) build their theory on the well-known fact that a mathematical learning process bases both on an active individual construction of knowledge and on acculturation into the mathematical practices of some society such as a classroom, a group of mathematicians working on the same field etc. The aim of this theory is to provide tools for discussing teachers' and students' activity in learning situations. The fundamental idea of the theory is that, in distinction to general social norms that sustain classroom microcultures, there also are norms that are specific to the mathematical activities. A concrete example of this is the common phenomenon that students who are active and social in science or language classes may turn passive and antisocial in the mathematics classroom since they do not find an appropriate way to express their mathematical thinking or to communicate with a teacher.

Originally, Yackel and Cobb concentrated on analysing mathematical discussions - for example, explanation, justification, and argumentation - but the sociomathematical norms also guide learners' other mathematical activities such as participation in small-group interactions (Yackel, Cobb, \& Wood, 1991). An example of the sociomathematical norm is the one that instructs a student when and how it is suitable for him/her to contribute to a discussion during the lecture. These norms are not solely defined by a teacher; the notion of mathematical difference is used to illustrate that the sociomathematical norms are interactively constituted more or less by all participants.

As our research questions show, we do not study any cognitive processes related to study habits or using learning materials but focus only on relative frequencies between various habits and material types and on finding variables that may explain the observed variation in these frequencies. In other words, we do not study any latent variables related to study habits or learning materials. However, we recall shortly the fact that the notion of learning material is far from being trivial. The following two examples demonstrate that there are several schools or traditions defining what learning materials, and especially, digital learning materials are exactly.

Lewis (2019) writes about teaching and learning materials: "the term refers to a spectrum of educational materials that teachers use in the classroom to support specific learning objectives, as set out in lesson plans", whereas for Nokelainen (2006, p. 179), learning material can be any material that is designed for educational 
purposes. When digital learning materials are concerned, he adds a requirement that the material is published in a digital form and intended to be accessed by a computer. A significant difference between these traditions is the following. The former definition focuses on the teacher perspective and is contextualised to a (physical or virtual) classroom. Moreover, it also assumes that a specific learning object has been determined in advance by the authors of the material. The latter definition also speaks about the educational purposes but leaves the learning objects and the principal user unspecified. Moreover, the use of such material is not restricted to any place or time, only accessibility by a computer is required from a digital learning material. A common feature in these definitions is that the format and the platform of learning materials can be diverse. Nowadays, the same applies also to the hardware, many students prefer a mobile phone or a tablet instead of a computer.

In this study, we base on the latter definition and accept, for example, any social media as a learning material (or a platform for accessing relevant mathematical knowledge) if a student him-/herself has considered it relevant. For a wider discussion about digital curriculum materials, i.e., the organised systems of digital resources in electronic formats that articulate a scope and sequence of curricular content, we refer to Pepin, Choppin, Ruthven and Sinclair (2017).

\section{Previous research}

Study habits are a traditional topic for research in mathematics education. In addition to international surveys such as PISA and TIMSS - where the study habits are considered most often as explanatory factors for learning results - in the 2000s, this tradition however seems to have been most actively cultivated outside Europe and in Africa especially. In Africa, for example, Akinsola, Tella, and Tella (2007) have studied how students' achievement in university mathematics depends on their skills to manage time in studying. Not surprisingly, procrastination in studies weakens the achievement.

On the other hand, the rise of ICT in mathematics education has made study habits a more actual topic for educational research also in western countries. For example, the importance of being able to self-regulate one's learning strategies becomes even greater when studying becomes more independent of time and space in digital learning environments. Broadbent's and Poon's (2015) systematic review of the topic shows that time management, metacognition, effort regulation, and critical thinking skills all are important factors in predicting achievement in online higher education 
learning environments. The identification of the significant indicators and predictors of achievement using the learning management data from digital learning environments is indeed a hot topic for the system developers. For example, You (2016) reports on the measures of self-regulated learning that are significant to achievement. Most often, such measures are time-based, yet the achievement can be predicted better by focusing on studying qualitatively what activities a learner focuses on in a learning environment.

PISA and TIMSS also explore the use of learning materials in mathematics education in secondary school. In short, printed textbooks are still most often used materials in the Finnish secondary mathematics education, and they are used regularly. However, textbooks are not used up to their full potential. Lepik, Grevholm and Viholainen (2015) and Viholainen, Partanen, Piiroinen, Asikainen and Hirvonen (2015) have reported from a survey of mathematics teachers' self-reported practices of textbook use in upper secondary schools in Finland, Estonia, and Norway. The authors of the former, large-scale study summarise their findings concerning Finland by saying that textbooks are a crucial resource for exercises, but about $45 \%$ of the Finnish teachers use them merely as a source of exercises. There are also studies showing that both the character of a teacher - e.g., the work experience, age, beliefs, etc. - and the character of the learning materials influence how a teacher interacts with the material (e.g. Remillard \& Bryans, 2004). A consequence is that many students do not get guidance for using textbooks as multifaceted learning resources. On the other hand, it is well-known that many mathematics teachers prepare themselves material that they use versatilely instead of printed books. Anyway, the latter study shows that mathematics teachers themselves may use the printed textbooks extensively in planning and conducting their teaching, but from the students' perspective, these are first and foremost a source of exercises.

To sum up, our literature review indicates that mathematics students' and teachers' intentions and views of the use of learning material may be more different from one another than one might expect. It is not at all evident that all students have learnt to make good use of learning resources in mathematics by the end of secondary education. 


\subsection{Questionnaire and data collection}

The collection of data was conducted using a questionnaire which was originally designed by two authors. The design was based on the theoretical framework and the questionnaire used in the previous study by Tossavainen, Rensaa, and Johansson (2019). All authors analysed and revised the first and following versions of the questionnaire before the final version was completed.

In addition to a section surveying a respondent's educational background, the questionnaire contains three sets of five-point Likert scales related to study habits, the use of different learning materials and knowledge sources, and the respondent's views of the nature of mathematics and him-/herself as a learner of mathematics. The last set is excluded from this study because it will be used in another study. The English translations of the items in the other two sets and the coding of the Likert scales are given in the Appendix.

Data for this study were collected during an ordinary lecture on three courses, without giving any information about the study in advance, at two campuses of one Finnish university. The courses are intended to be taken in the first and third year. The students participated on a voluntary basis, and the data contains almost all students from the involved courses. The participants $(N=98)$ are 1) student teachers (i.e., subject teachers or primary school teachers with 60 ETCS minor studies in mathematics), 2) the students of mathematics without intention to become a teacher, 3) the students of applied physics with 39-6o ETCS minor studies in mathematics, or 4) the students of other subjects. The number of students in the lastly mentioned group is eight, and they are excluded from the analyses that concern the third research question (due to the small group size). All participants are Finnish.

The university courses related to this study are traditional lecture courses or flipped classroom courses. The traditional lecture courses consist of classroom lectures and practicals. In practicals, correct solutions to homework exercises are looked through in a teacher-led whole class discussion. There is also an improved approach to practicals in use, where students first have a small group discussion about the exercises they have solved, and then the solutions are revised in a teacher-led whole class discussion. Learning material in traditional lecture courses depends on the subject and the teacher, including for example lecture slides, lecture notes, a course book and exercises. In the flipped classroom approach, classroom lectures are 
replaced with pre-material, typically online videos, which students study individually. After studying the pre-material, students attend face-to-face meetings that are devoted to student-centered learning activities allowing students to utilize the expertise of the teacher in their learning process. Furthermore, the implementation of practicals in flipped classroom courses is like the traditional lecture course case. The principal learning material in flipped classroom courses is comprises of videos, slides and notes written by the teacher, a course book, and exercises. For information on the flipped classroom approach in physics, we refer to Saarelainen and Heikkinen (2013) and Mäkitalo-Siegl, Kankaanpää, Heikkinen, and Saarelainen (2016).

\subsection{Analyses}

The data were analysed using SPSS 25 software. The analyses are based on, e.g., the use of Student's t-tests, One-way ANOVA, Spearman correlations, the effect sizes (Cohen's d) and the computation of the usual descriptive statistics. For the limit values of the effect sizes, we refer to Sawilowsky (2009).

\subsection{Limitations}

In this research, we have concentrated on studying how much students use different kinds of learning materials in university mathematics courses. Considering also in what ways students use the material would enable us to study, for example, student achievement in relation to learning materials. Further, it is plausible that the way how teachers themselves use learning materials in these courses also affects the students' use of learning materials, cf. Remillard \& Bryans (2004). In our questionnaire, this effect was not separately measured but imbedded in the sociomathematical norms.

The questionnaire was conducted among groups of students whose learning environments differ in some key aspects. A concrete example of this is that the flipped learning methodology is more widely used at one of the campuses. In other words, at this campus, students get more support for taking video-based learning materials in use. Again, the role of this kind of support was not measured separately but taken into account as a part of the sociomathematical norms.

Finally, we also point out that the research data were collected during classroom lectures. Therefore, students who prefer to study without attending lectures probably are underrepresented in our data. 


\section{Results}

Before answering our first research question, we recall that the Likert scales surveying students' study habits and use of learning materials are given in the Appendix. The number of items surveying the study habits is fifteen and eleven items focus on the use of learning materials. Further, to show that there is enough variation in the grades for conducting meaningful correlation analyses, we record the distributions of the respondents' grades in the national matriculation exams in Table 1. For the readers, who do not know the assessment scale of these exams, we refer to Ylioppilastutkinto (2020).

Table 1. Distributions of the respondents' grades in the matriculation exams

\begin{tabular}{lll}
\hline Grade & $\begin{array}{l}\text { Mathematics } \\
(N=97)\end{array}$ & $\begin{array}{l}\text { Mother tongue } \\
(N=96)\end{array}$ \\
\hline I & 0 & 1 \\
A & 0 & 4 \\
B & 2 & 11 \\
C & 17 & 18 \\
M & 33 & 30 \\
E & 31 & 19 \\
L & 14 & 13 \\
\hline
\end{tabular}

In light of the above facts, the results from the Spearman correlation analysis may be considered quite surprising: only one item (1.15) related to study habits correlates with the grade in the mathematics matriculation exam $(\rho=0.22, p<0.05)$ and none of them with the grade in the mother tongue matriculation exam. Further, none of the items related to the use of learning materials correlates with the grade in mathematics, but three items $(2.6,2.7$, and 2.10) correlate with the grade in mother tongue. The correlation coefficients are $\rho=-0.25, p<0.05 ; \rho=-0.21, p<0.05$; and $\rho=-0.21, p<0.05$, respectively.

In other words, the higher grade in the mathematics matriculation exam is related only to higher interest in mathematical hobbies also in one's spare time. The negative correlations between the grade in mother tongue and Items 2.6, 2.7, and 2.10 means that the students with a higher grade use both printed and electronical textbooks somewhat less than students with a lower grade. We discuss these findings and why they are surprising more thoroughly in Section 6.

Our second research question examines the effect of the national core curricula. Here we have divided the participants into two groups according to the year of their 
exam. There is a natural choice for the cut point because the new national curricula for upper secondary schools were implemented in 2016. Consequently, those who have taken their exam 2017 or later have also studied mathematics in upper secondary school under the curriculum that assumes the use of digital learning environments in mathematics.

Table 2 shows only those items where the mean difference is significant with $p<$ 0.05 in the Student's independent samples t-test. The items where the mean difference is significant at the level $p<0.01$ are denoted with the asterisk $(*)$. The students in Group Y ("the younger") have taken the exam in 2017-2019, the students in Group O ("the older") in 2001-2016. Note also that the number of the respondents varies slightly across the items; the intervals are shown in the table.

Table 2. The significant differences in study habits and in the use of learning materials between the younger and older students

\begin{tabular}{lllll}
\hline Item & $\begin{array}{l}\text { Group } \mathbf{Y} \\
(N=54-55) \\
\text { Mean }\end{array}$ & Std. dev. & $\begin{array}{l}\text { Group O } \\
(N=37-40) \\
\text { Mean }\end{array}$ & Std. dev. \\
\hline 1.6 & 2.11 & 1.03 & 2.58 & 1.11 \\
$1.7^{*}$ & 4.11 & 0.96 & 3.48 & 1.04 \\
1.10 & 3.52 & 1.36 & 4.10 & 1.03 \\
1.12 & 2.85 & 1.25 & 3.48 & 0.99 \\
1.13 & 4.00 & 1.12 & 3.49 & 0.96 \\
$2.5^{*}$ & 1.55 & 1.03 & 2.54 & 1.55 \\
2.6 & 1.54 & 1.08 & 2.05 & 1.40 \\
$2.7^{*}$ & 1.37 & 1.00 & 2.05 & 1.28 \\
\hline
\end{tabular}

$*=p<.01$

Table 2 reveals some interesting differences in study habits between the younger and the older students: the older are braver to ask the lecturer (1.6) whereas the younger more often turn to their fellow students (1.7) when they need help with understanding the content of a lecture. Further, the older are more active to communicate with the teacher of the practicals (1.12) and edit their own solutions during the session (1.10) than the younger who communicate more with the other students in issues related to the practicals (1.13). The differences in Items 2.5-7 also speak for the fact that the older are more independent and self-directed and read more literature. What may be a little less expected is the outcome of 2.7, i.e., that this finding concerns also electronical books and journals. Moreover, it is worth mentioning that the group means are lower in 2.7 than in $2.5^{-6}$ (yet the mean differences are not 
significant at the level $p<0.05$ ). In other words, electronical materials are not more popular than printed materials in either group.

Table 3 shows the means and standard deviations of the study habit items in three groups that represent three different study programmes. The items where there are significant mean differences in the Bonferroni post hoc test of One-way ANOVA are indicated with the asterisks. As already said, the first two groups study at the same campus, whereas the third group at the other campus. Therefore, in the comparisons of the last group with other groups, we have no possibilities to separate the effect that is due to the local sociomathematical norms from the effect that is due to the fact that these students study in a different programme. Thus, the effect of the study programme can be studied only between the first two groups who study the same courses. This applies to Table 4, too.

Table 3. The descriptive measures of study habits across the study programmes

\begin{tabular}{|c|c|c|c|c|c|c|c|c|}
\hline \multirow[t]{2}{*}{ Item } & \multicolumn{2}{|c|}{$\begin{array}{l}\text { Teachers } \\
(N=39)\end{array}$} & \multicolumn{2}{|c|}{$\begin{array}{l}\text { Mathematicians } \\
(N=18)\end{array}$} & \multicolumn{2}{|c|}{$\begin{array}{l}\text { Physicists } \\
(N=33)\end{array}$} & \multicolumn{2}{|c|}{$\begin{array}{l}\text { Total } \\
(N=94-98)\end{array}$} \\
\hline & Mean & Std. dev. & Mean & Std. dev. & Mean & Std. dev. & Mean & Std. dev. \\
\hline 1.1 & 4.67 & 0.62 & 4.50 & 0.79 & 4.76 & 0.61 & 4.66 & 0.64 \\
\hline $1.2^{* *}$ & 4.72 & 0.61 & 4.39 & 0.85 & 4.94 & 0.24 & 4.71 & 0.61 \\
\hline $1.3^{*}$ & 4.44 & 0.72 & 4.39 & 0.85 & 4.81 & 0.40 & 4.56 & 0.68 \\
\hline $1.4^{* *}$ & 1.79 & 0.70 & 1.83 & 0.86 & 2.76 & 1.03 & 2.14 & 0.95 \\
\hline 1.5 & 3.31 & 1.00 & 3.50 & 1.15 & 3.73 & 0.91 & 3.50 & 0.98 \\
\hline 1.6 & 2.18 & 0.97 & 2.00 & 1.09 & 2.76 & 1.12 & 2.35 & 1.10 \\
\hline 1.7 & 3.82 & 0.94 & 3.50 & 1.20 & 4.15 & 0.97 & 3.86 & 1.04 \\
\hline 1.8 & 1,36 & 0.87 & 1.88 & 1.41 & 1.42 & 0.94 & 1.52 & 1.08 \\
\hline 1.9 & 3.05 & 1.08 & 3.61 & 1.20 & 3.15 & 0.97 & 3.21 & 1.07 \\
\hline 1.10 & 3.74 & 1.25 & 3.22 & 1.56 & 4.06 & 1.09 & 3.75 & 1.24 \\
\hline 1.11 & 2.37 & 1.30 & 2.89 & 1.61 & 2.88 & 1.19 & 2.70 & 1.33 \\
\hline $1.12 * *$ & 3.00 & 1.03 & 2.56 & 1.50 & 3.58 & 1.03 & 3.15 & 1.19 \\
\hline 1.13 & 3.82 & 1.04 & 3.39 & 1.29 & 4.06 & 0.96 & 3.80 & 1.09 \\
\hline 1.14 & 1.49 & 1.05 & 1.78 & 1.22 & 1.36 & 0.93 & 1.51 & 1.05 \\
\hline $1.15^{* *}$ & 1.54 & 0.68 & 2.33 & 1.14 & 2.09 & 1.07 & 1.90 & 1.02 \\
\hline
\end{tabular}

$*=p<.05 ; \quad * *=p<.01$

In Items 1.2 and 1.3, there are statistically significant differences and even the effect size is large between Mathematicians and Physicists in $1.2(d=0.88)$, and medium in $1.3(d=0,63)$. In practice, one must, however, interpret these items so that students in all groups are active to participate in small-group practicals, and they actively do their exercises in advance, yet the students of applied physics are the most active with respect to both issues. From a practical point of view, a more remarkable 
difference is seen in 1.4. Physicists are clearly more active to study the lecture material before the lecture. Here the effect size between Teachers and Physicists is large, almost very large $(d=1.10)$, and large between Mathematicians and Physicists $(d=$ 0.95). Further, there is no difference between Teachers and Mathematicians. We hypothesize that these findings are more due to differences in local study cultures than due to different study programmes.

It is interesting to also review the mean differences between the items. The high means in 1.1-3 indicate that the students in general are active to participate in lectures and practicals. The means in 1.5, 1.9, 1.10 are already somewhat lower, yet in the interval 3-4, which show that the students are quite active also in studying the learning material after lectures and during the practicals. Further, they are quite active to ask for help from the fellow students (1.7 and 1.13) but not as active to ask for help from the lecturer or the small-group teacher (1.6 and 1.12); the respective mean differences in Student's paired samples t-test are significant in both cases (1.7 vs. 1.6: $\mathrm{t}(97)=11.48, p<0.001$; 1.13 vs. 1.12: $t(93)=4.58, p<0.001)$. In the first pair, the effect size is large, almost very large $(d=1.16)$. The low means but large standard deviations in 1.8 and 1.14 reveal that only a few students seek support for their mathematical studies on the social media.

Table 4 contains three items where the mean differences are statistically significant. Item 2.4 shows that Mathematicians are most active to study the given solutions to exercises in the small group practicals, whereas there is no difference between Teachers and Physicists in this issue. Hence, we can conclude that the difference is mostly due to different study programmes; the students of (pure) mathematics are probably more motivated to study also the alternative solutions given at the practicals and have more mathematical hobbies in their spare time, $\mathrm{cf}$. Items 1.9 and 1.15 in Table 3. 
Table 4. The descriptive measures of the use of learning materials across the study programmes

\begin{tabular}{|c|c|c|c|c|c|c|c|c|}
\hline \multirow[t]{2}{*}{ Item } & \multicolumn{2}{|c|}{$\begin{array}{l}\text { Teachers } \\
(N=39)\end{array}$} & \multicolumn{2}{|c|}{$\begin{array}{l}\text { Mathematicians } \\
(N=18)\end{array}$} & \multicolumn{2}{|c|}{$\begin{array}{l}\text { Physicists } \\
(N=33)\end{array}$} & \multicolumn{2}{|c|}{$\begin{array}{l}\text { Total } \\
(N=96-98)\end{array}$} \\
\hline & Mean & Std. dev. & Mean & Std. dev. & Mean & Std. dev. & Mean & Std. dev \\
\hline 2.1 & 4.26 & 1.07 & 3.89 & 1.61 & 4.61 & 1.00 & 4.32 & 1.20 \\
\hline 2.2 & 4.56 & 0.88 & 4.61 & 0.78 & 4.76 & 0.75 & 4.62 & 0.82 \\
\hline 2.3 & 4.23 & 1.01 & 4.39 & 0.85 & 4.30 & 0.88 & 4.32 & 0.90 \\
\hline $2.4^{*}$ & 3.56 & 1.27 & 4.29 & 1.05 & 3.58 & 1.23 & 3.75 & 1.21 \\
\hline $2.5^{*}$ & 1.58 & 1.08 & 2.00 & 1.57 & 2.27 & 1.49 & 1.95 & 1.35 \\
\hline 2.6 & 1.71 & 1.35 & 2.00 & 1.37 & 1.72 & 1.11 & 1.75 & 1.23 \\
\hline 2.7 & 1.45 & 1.03 & 1.56 & 1.15 & 1.97 & 1.33 & 1.66 & 1.16 \\
\hline $2.8 * *$ & 3.11 & 1.43 & 2.33 & 1.50 & 3.79 & 1.22 & 3.26 & 1.45 \\
\hline 2.9 & 2.97 & 1.33 & 2.78 & 1.44 & 3.09 & 1.31 & 2.99 & 1.30 \\
\hline 2.10 & 2.78 & 1.40 & 2.89 & 1.64 & 3.48 & 1.12 & 3.11 & 1.35 \\
\hline 2.11 & 1.77 & 1.22 & 1.71 & 1.26 & 1.64 & 1.22 & 1.72 & 1.23 \\
\hline
\end{tabular}

$*=p<.10 ; \quad * *=p<.01$

By Item 2.5, Teachers are less active to use the course literature. Again, one may interpret that this difference is mostly due to different study programmes; the student teachers focus on the material discussed during the lectures; the other students seek also the background knowledge. On the other hand, the means for all groups are rather low in this item and the standard deviations are quite large. The observed mean differences are thus due to a relatively small number of students.

Item 2.8 reveals an interesting difference that seems to be due to both differences in local study cultures and different study programmes: Mathematicians are clearly less active to use videos than other students, whereas physicists are quite active to use them. We discuss this finding in more detail in Section 6.

The comparison of means between the items reveals some interesting differences in the use of learning materials. That all students are active to use their own lecture notes is not surprising, but that the solutions for the exercises are not actively used is. Indeed, the mean difference between Items $2.2(\bar{x}=4.65)$ and $2.4(\bar{x}=3.75)$ is significant $(t(96)=6.87, p<0.001)$ with almost large effect size $(d=0.70)$. The use of complementary literature is however only rare (2.6-7) except for material to be found on the Internet (2.10). In 2.10, the mean differences are actually quite large but so are also the standard deviations, therefore the mean differences are not significant at level $p<0.05$. Item 2.11 confirms the finding which we already have mentioned; the social media are not important sources of mathematical knowledge for a majority of students. 


\section{Discussion and conclusions}

In our data, the higher grade in the mathematics matriculation exam is related only to higher interest in mathematical hobbies also in one's spare time, not to any specific study habits. This finding is surprising and, perhaps, of a greater value, from the following perspective. There are studies showing that the grade in mathematics matriculation exam is a strong predictor of achievement in almost any other subject (e.g., Kupiainen, Marjanen, \& Hautamäki, 2016). Our finding does not conflict the previous research or challenge the practice related to admission to university but merely suggests that the better achievement is based more on students' personal features and the quality of studying than on the versatility of study habits and used learning materials. As also Tossavainen's and Juvonen's (2015) study shows, the higher intrinsic motivation in mathematics and having an interest in mathematics also outside school are related to one another. Our finding can thus be explained by saying that the correlation between the grade and Item 1.15 is due to a variation in the students' intrinsic motivation in mathematics. An interesting question for future research is, of course, what is the mechanism behind the correlation of the grade in the mathematics matriculation exam and achievement in further studies if the effect of higher grades is not observable in the study habits.

The negative correlations between the grade in mother tongue and Items 2.6, 2.7, and 2.10 is somewhat more difficult to explain since also the grade in mother tongue is a good predictor of achievement in many subjects (Kupiainen, 2017). Our finding was that the students with a higher grade use both printed and electronical textbooks less than students with a lower grade. The effect sizes in the correlations are not large, yet remarkable to some extent. Our interpretation is that linguistically talented students may benefit from the materials distributed by the lecturer and the teacher of the practicals better than those students who are not equally competent in languages. A very recent study by Prat et al. (2020) shows that students with good ability to learn languages are also good at learning programming languages. In their study, linguistic competence was even more significant than the mathematical competence.

The differences between the younger and older students that are shown in Table 2 probably have not much to do with the revision of the national core curriculum but are more due to the fact that the older students simply are more advanced in the transition to adulthood. In other words, the older students are more independent and self-directed and, therefore, they also read more literature. They can also meet the lecturer and the teacher of the practicals at a more equal level and hence they are more 
active to communicate with them when they want to have help with the content of teaching. What may be a little less expected is the outcome of 2.7, i.e., that the older students also use more often electronical books and journals. Once again, the large standard deviations however indicate that this is mostly due to a smaller group of students; many students do not use these sources regardless of their age.

Our answer to the last research question reveals several differences between the student groups. As we have pointed out, our data do not allow us to separate in all cases whether the difference is due to differences in the local sociomathematical norms or that the groups represent different study programmes. An overall view however is that the students of applied physics differ from the other two groups more than the student teachers and the students of (pure) mathematics from one another.

A plausible explanation for the difference between the applied physics students and the other students is the fact that, at the campus where the applied physics students study, cooperative learning plays an important role. The students at the campus are strongly encouraged to work together from the beginning of their studies. For example, they typically solve the exercises in small groups before the practicals, cf. Item 1.3. Furthermore, various measures to support the integration of students into the academic community as early as possible are used, and the students' role as active members of the community is highlighted. Thus, these students actively participate in small group practicals and are used to asking help from the teacher of the practicals which also Items 1.2 and 1.12 show. As already mentioned in Section 4.3, a lot of effort has also been invested in using the flipped classroom approach. Items 1.4 and 2.8 give illustrative evidence for the results of using the flipped classroom approach: the students of applied physics study lecture material in advance and use videos while studying more often than the other students; not only in the flipped classroom courses but also in the traditional lecture courses.

A finding that can be interpreted to demonstrate the other end of sociomathematical norms is related to Items 1.6 and 1.12. The students of (pure) mathematics were least active to communicate with the lecturer and the teacher of the practicals (yet the mean difference is significant at the level $p<0.05$ only in the latter issue). A possible explanation is that these students appreciate individual and selfsufficient working methods more than other students. Whether this is good or bad, we leave this topic open for a further debate. We mention only that we did not find any evidence in our data that these students were less satisfied with their studies in 
mathematics. For example, although their mean in 1.2 is lower than that of the other groups, they still participate in the practicals actively.

An interesting finding is also that the students in general are not active users of social media when they study mathematics. Perhaps, this tells about the sociomathematical norms at both campuses. Although the use of videos is already encouraged and supported (at least, at one of the campuses), the role of social media is considered less important. One reason for this may be that many university teachers are not used to distribute their materials via social media but as downloads (or videos) at the homepage of the course. A crucial difference between these distribution formats is that, in social media, you are expected to be available at least every now and then, whereas, at the homepage of a course, it is sufficient that the documents are found there.

The most significant result in Table 4 becomes visible as we recall the findings of Lepik, Grevholm, and Viholainen (2015) and Viholainen, Partanen, Piiroinen, Asikainen, and Hirvonen (2015): the transition from upper secondary school mathematics to university mathematics also contains a transition from the heavy use of (printed) text books to studying mostly with the help of lecture notes, handouts and material for and from the practicals. The shift seems to be comprehensive when one compares the means, for example, in Items 2.1 and 2.5 with the results of the abovementioned articles. For a learner with some kind of dyslexia, this change can be insurmountable in spite of other relevant competences. Indeed, many handouts do not make use of colours, varying font-size or other layout tools for highlighting the central definitions and theorems, giving concrete examples, etc. This topic would clearly deserve more attention.

\section{References}

Akinsola, M.K., Tella, A., \& Tella, A. (2007). Correlates of academic procrastination and mathematics achievement of university undergraduate students. Eurasia Journal of Mathematics, Science \& Technology Education, 3(4), 363-370. DOI 10.12973/ejmste/75415

Blasco-Arcas, L., Buil, I., Hernández-Ortega, B., \& Sese, F. J. (2013). Using clickers in class. The role of interactivity, active collaborative learning and engagement in learning performance. Computers \& Education, 62, 102-110. DOI 10.1016/j.compedu.2012.10.019

Broadbent, J. \& Poon, W. L. (2015). Self-regulated learning strategies \& academic achiement in online higher education learning environments: A systematic review. The Internet and Higher Education, 27(October), 1-13. DOI 10.1016/j.iheduc.2015.04.007

Fan, L. Zhu, Y., \& Miao, Z. (2013). Textbook research in mathematics education: development status and directions. ZDM Mathematics Education, 45, 633-646. DOI 10.1007/s11858013-0539-X 
Holzinger, A., Kickmeier-Rust, M., \& Albert, D. (2008). Dynamic Media in Computer Science Education; Content Complexity and Learning Performance: Is Less More? Educational Technology \& Society, 11(1), 279-290.

Kupiainen, S. (2017). Ylioppilas opiskelijavalintojen pyörteessä. Seminaari opiskelijavalintojen kehittämisestä Haaga-Helia 7.11.2017. Retrieved from https://minedu.fi/documents/1410845/5626566/Sirkku+Kupiainen+Opiskelijavalinta.pdf /o3baa728-4fo2-4b76-a515-e67a5ecbo139/Sirkku+Kupiainen+Opiskelijavalinta.pdf

Kupiainen, S., Marjanen, J., \& Hautamäki, J. (2016). The problem posed by exam choice on the comparability of results in the Finnish matriculation examination. Journal for educational research online, 8(2), 87-106.

Lepik, M., Grevholm, B. \& Viholainen, A. (2015). Using textbooks in the mathematics classroom the teachers' view. Nordic Studies in Mathematics Education, 20(3-4), 129-156.

Lewis, B. (2019). TLM: Teaching/Learning Materials. Retrieved from https://www.thoughtco.com/tlm-teaching-learning-materials-2081658

Metsämuuronen, J. (2017). Oppia ikä kaikki - matemaattinen osaaminen toisen asteen koulutuksen lopussa 2015. Julkaisut 1:2017. Helsinki, Finland: Kansallinen koulutuksen arviointikeskus.

Mäkitalo-Siegl, K., Kankaanpää, J., Heikkinen, L., \& Saarelainen, M. (2016). Higher education students' experiences on flipped classroom in physics. The European Association for Practitioner Research on Improving Learning (EAPRIL) 2016 conference, Porto, Portugal.

Nokelainen, P. (2006). An empirical assessment of pedagogical usability criteria for digital learning material with elementary school students. Journal of Educational Technology \& Society, 9(2), 178-197.

Pepin, B., Choppin, J., Ruthven, K., \& Sinclair, N. (2017). Digital curriculum resources in mathematics education: foundations for change. ZDM Mathematics Education, 49(5), 645661. DOI 10.1007/s11858-017-0879-z

Prat, C. S., Madhyastha, T. M., Mottarella, M. J. et al. Relating Natural Language Aptitude to Individual Differences in Learning Programming Languages. Scientific Reports, 10, Article 3817. DOI 10.1038/s41598-020-60661-8

Remillard, J. T., \& Bryans, M. B. (2004). Teachers' orientations toward mathematics curriculum materials: Implications for teacher learning. Journal for Research in Mathematics Education, 35(5), 352-388. DOI 10.2307/30034820

Roy, G. J., Tobias, J. M., Safi, F. \& Dixon, J. K. (2014). Sustaining social and sociomathematical norms with prospective elementary teachers in a mathematics content course.

Investigations in Mathematics Learning, 7(2), 33-64. DOI 10.1080/24727466.2014.11790341

Saarelainen, M., \& Heikkinen, L. (2013) Oppijakeskeisistä opiskelutaidoista eväät fyysikon uralle. Yliopistopedagogïkka, 2o(1), 11-15.

Sawilowsky, S. S. (2009). New effect size rules of thumb. Journal of Modern Applied Statistical Methods, 8(2), 597-599. DOI 10.22237/jmasm/1257035100

Stevens, T., Olivárez, A., Lan, W. Y., \& Tallent-Runnels, M. K. (2004). Role of mathematics selfefficacy and motivation in mathematics performance across ethnicity. Journal of Educational Research, 97, 208-221. DOI 10.3200/JOER.97.4.208-222

Tossavainen, T., \& Juvonen, A. (2015). Finnish primary and secondary students' interest in music and mathematics relating to enjoyment of the subject and perception of the importance and usefulness of the subject. Research Studies in Music Education, 37(1), 107-121. DOI $10.1177 / 1321103 X 15589259$

Tossavainen, T., Rensaa, R. J., \& Johansson, M. (2019). Swedish first-year engineering students' view of mathematics, self-efficacy and motivation and their effect on task performance. 
International Journal of Mathematical Education in Science and Technology. DOI 10.1080/0020739X.2019.1656827

Viholainen, A., Partanen, M., Piiroinen, J., Asikainen, M. \& Hirvonen, P. E. (2015). The role of text-books in Finnish upper secondary school mathematics: theory, examples and exercises. Nordic Studies in Mathematics Education, 2O(3-4), 157-178.

Yackel, E., \& Cobb, P. (1996). Sociomathematical norms, argumentation, and autonomy in mathematics. Journal for Research in Mathematics Education, 27, 458-477. DOI $10.2307 / 749877$

Yackel, E., Cobb, P., \& Wood, T. (1991). Small-group interactions as a source of learning opportunities in second-grade mathematics. Journal for Research in Mathematics Education, 22, 390-408. DOI 10.2307/749187

Ylioppilastutkinto (2020). Matriculation examination. Retrieved from https://www.ylioppilastutkinto.fi/en

You, J. W. (2016). Identifying significant indicators using LMS data to predict course achievement in online learning. The Internet and Higher Education, 29(April), 23-30. DOI 10.1016/j.iheduc.2015.11.003 


\section{Appendix - The study habits and learning material items in the questionnaire}

\section{How often do you do the following things during a mathematics course?}

\begin{tabular}{|c|c|c|c|c|c|}
\hline & $1=$ Never & $\begin{array}{l}2=\text { Only } \\
\text { when I } \\
\text { prepare } \\
\text { myself } \\
\text { for an } \\
\text { exam }\end{array}$ & $\begin{array}{l}=A \\
\text { couple } \\
\text { of times } \\
\text { under } \\
\text { the } \\
\text { course }\end{array}$ & $\begin{array}{l}4=2-4 \\
\text { times a } \\
\text { month }\end{array}$ & $\begin{array}{l}5=\text { Once } \\
\text { a week } \\
\text { or more } \\
\text { often }\end{array}$ \\
\hline 1.1 I participate in the lectures of the course & & & & & \\
\hline 1.2. I participate in the small-group practicals & & & & & \\
\hline 1.3. I solve exercises before the practicals. & & & & & \\
\hline 1.4. I read the lecture material before the lecture. & & & & & \\
\hline 1.5. I study the lecture material after the lecture. & & & & & \\
\hline $\begin{array}{l}\text { 1.6. I ask for help from the lecturer if something about } \\
\text { the lecture or the lecture material is unclear to me. }\end{array}$ & & & & & \\
\hline $\begin{array}{l}\text { 1.7. I ask for help from my student fellows if something } \\
\text { about the lecture or the lecture material is unclear to me. }\end{array}$ & & & & & \\
\hline $\begin{array}{l}\text { 1.8. I ask for help from a social media discussion group if } \\
\text { something about the lecture or the lecture material is } \\
\text { unclear to me. }\end{array}$ & & & & & \\
\hline $\begin{array}{l}\text { 1.9. After the practical, I study the correct solution which } \\
\text { we were given at the session. }\end{array}$ & & & & & \\
\hline $\begin{array}{l}\text { 1.10. I correct and improve my own solution during the } \\
\text { practical. }\end{array}$ & & & & & \\
\hline $\begin{array}{l}\text { 1.11. I correct and improve my own solution after the } \\
\text { practical. }\end{array}$ & & & & & \\
\hline $\begin{array}{l}\text { 1.12. I ask for help from the teacher of practical if } \\
\text { something about the exercises is unclear to me. }\end{array}$ & & & & & \\
\hline $\begin{array}{l}\text { 1.13. I ask for help from my fellow students if something } \\
\text { about the exercises is unclear to me. }\end{array}$ & & & & & \\
\hline $\begin{array}{l}\text { 1.14. I ask for help from a social media discussion group } \\
\text { if something about the exercises is unclear to me. }\end{array}$ & & & & & \\
\hline $\begin{array}{l}\text { 1.15. I spend my time on mathematical hobbies also in } \\
\text { my spare time (e.g., programming). }\end{array}$ & & & & & \\
\hline
\end{tabular}

\section{How often do you use the following materials or sources while you study mathematics?}

\begin{tabular}{|c|c|c|c|c|c|}
\hline & $\mathbf{1}=$ Never & $\begin{array}{l}2=\text { Only } \\
\text { when I } \\
\text { prepare } \\
\text { myself } \\
\text { for an } \\
\text { exam }\end{array}$ & $\begin{array}{l}3=A \\
\text { couple } \\
\text { of times } \\
\text { under } \\
\text { the } \\
\text { course }\end{array}$ & $\begin{array}{l}4=2-4 \\
\text { times a } \\
\text { month }\end{array}$ & $\begin{array}{l}5=\text { Once } \\
\text { a week } \\
\text { or more } \\
\text { often }\end{array}$ \\
\hline \multicolumn{6}{|l|}{ 2.1. My own lecture notes } \\
\hline \multicolumn{6}{|c|}{ 2.2. The materials given by the lecturer (e.g., handouts) } \\
\hline \multicolumn{6}{|c|}{ 2.3. The course exercises defined by the lecturer } \\
\hline \multicolumn{6}{|l|}{ 2.4. The solutions for the exercises } \\
\hline \multicolumn{6}{|c|}{ 2.5. The textbooks mentioned in the course curriculum } \\
\hline \multicolumn{6}{|c|}{ 2.6. Other printed textbooks } \\
\hline \multicolumn{6}{|c|}{$\begin{array}{l}2.7 \text {. Electronical books and journals (excluding course } \\
\text { books) }\end{array}$} \\
\hline \multicolumn{6}{|l|}{ 2.8. Videos made for the course you are studying } \\
\hline \multicolumn{6}{|l|}{ 2.9. Other relevant videos in Internet } \\
\hline \multicolumn{6}{|l|}{ 2.10. Other relevant digital material in Internet } \\
\hline 2.11. Social media discussion groups & & & & & \\
\hline
\end{tabular}

